\title{
Guest editor's introduction: so what is entrepreneurship research?
}

\author{
Gary J. Castrogiovanni ${ }^{1}$
}

Published online: 10 April 2018

(C) Springer Science+Business Media, LLC, part of Springer Nature 2018

Entrepreneurship journals publish such a wide range of research that it sometimes may seem unclear as to how two or more particular articles relate to the study of entrepreneurship and therefore fit within the aims and scope of entrepreneurship journals. It may be difficult, for example, to see how studies of family business succession and new venture finance have anything in common. Compounding this problem is the tendency for entrepreneurship scholars to be somewhat entrepreneurial by attempting to create new research niches that they can dominate. Typically, they carve out their own niches by inserting such adjectives as "corporate," "social," or "international" in front of "entrepreneurship" to indicate their focus.

So what is entrepreneurship research? I stumbled onto this question when I began studying franchise organizations in the early 1990s. I was an assistant professor trained in strategic management, and I decided to examine strategy research questions in the franchising context. Though I thought that I was doing strategy research, individuals who viewed franchising as part of the entrepreneurship field often pigeonholed it as entrepreneurship research. Over the next 10-15 years, my research and interests shifted increasingly toward entrepreneurship, and in 2006, I changed schools and moved into an entrepreneurship faculty line for the first time.

By then, I was a founding editor of the International Entrepreneurship and Management Journal (IEMJ) and an associate editor of the Journal of Small Business Management (JSBM). Around that time, JSBM was dropped from the Financial Times journal list because it was viewed more as a management journal than as an entrepreneurship journal. Questioning the validity of that decision in my own mind, I compared the content of the articles published over the past five years in Entrepreneurship Theory and Practice (ETP) and the Journal of Business Venturing (JBV) with the content of $J S B M$ articles during that same period. Both ETP and $J B V$ had a much higher proportion of articles focusing on new ventures than $J S B M$, and a much lower

Gary J. Castrogiovanni

castrogi@fau.edu

1 College of Business, Florida Atlantic University, Boca Raton, FL 33431, USA 
proportion of articles focusing on the management of established small and mediumsize businesses. ${ }^{1}$ In response to the Financial Times decision, JSBM added its current tagline, "Advancing Entrepreneurship Research Worldwide," or a very similar one. Whereas the Financial Times apparently did not consider small business management research to fall within the entrepreneurship field, the JSBM people certainly did.

As a journal editor over the next several years, it became clear that many authors defined the entrepreneurship field differently from the way that I defined it. I often had to consider questions of what is entrepreneurship research, and whether a particular paper seemed to fit. Though I tried to define the field broadly as IEMJ editor, for example, I still desk-rejected many papers that I felt had nothing to do with entrepreneurship.

This special issue examines some of the theoretical domains associated with entrepreneurship to distinguish them from one another, and to highlight how they fit within the entrepreneurship field, broadly defined. To accomplish this, papers representing various domains were selected. Some directly discuss the bounds and key questions within their domains, while others suggest the bounds indirectly as they focus on a particular topic within their domain.

We start with an article by Mahto and McDowell that deals with individual entrepreneurship by offering a theory of why someone decides to become an entrepreneur. They argue that identity is key to understanding entrepreneurial motivation. Next, Martinez-Climent, Zorio-Grima, and Ribeiro-Soriano consider how crowdfunding may provide the capital needed by independent entrepreneurs - usually individuals or founding teams - to start and develop their businesses. They present a bibliometric analysis of how the relatively new crowdfunding phenomenon has been treated it the literature thus far.

We then shift to focus on entrepreneurship in particular types of settings. Dheer reviews the literature on immigrant entrepreneurship. Among other things, he discusses its antecedents, outcomes, research gaps, and contributions to our broader understanding of entrepreneurship in general. Stewart focuses on professional service entrepreneurs. As he notes, a high proportion of professionals start their own businesses, and their experiences differ somewhat from entrepreneurs in other industries because they must consider professional norms and standards as they pursue their economic goals. Welsh and Kaciak examine female entrepreneurship. They offer their PerformanceInterference-Enrichment model to address the business-family-interface of women entrepreneurs. Lortie and Cox consider the boundaries of the social entrepreneurship research domain. They delineate that domain from others within the entrepreneurship field while also showing its relationship to domains within other fields such as strategic management and sociology.

Next, we move to entrepreneurial efforts within broader organizational entities. Drawing largely on the franchising literature, Madanoglu discusses economic and social exchange among entrepreneurial partnerships. In doing so, he offers a research agenda that extends beyond franchising to such areas as social and international entrepreneurship. Mazzei reviews literature on strategic entrepreneurship. Using a change management framework to exam the content, process, context, and outcomes

\footnotetext{
${ }^{1}$ This was my informal conclusion about the publications in those journals during the period mentioned, which was roughly 2002-2006. Their respective foci may be much different today.
} 
of strategic entrepreneurship, he offers suggestions for future research in that domain. Martin and Javalgi examined research in the international entrepreneurship domain over the past 24 years. In doing so, they discuss several key issues, gaps in the literature, and desirable directions for future research.

Finally, Kloepfer and Castrogiovanni offer an integrative perspective linking these various entrepreneurship research domains and others not addressed in this special issue. They view the entrepreneurship field as pertaining to various venture creation subprocesses, subdomains, and interfaces. Subprocesses pertain to opportunity exploration and exploitation, and can include environmental scanning, negotiating, organizing, and other relevant activities. Subdomains pertain to venture creation in various settings such as corporate entrepreneurship, international entrepreneurship, and professional entrepreneurship. Interfaces include family business, small business, and franchising. They are research areas that overlap with entrepreneurship but also address some important research questions that have nothing to do with venture creation.

It is impossible to address all research domains within the entrepreneurship field within this special issue. Moreover, new domains are likely to be discovered or developed as the field evolves. This special issue serves to highlight and embrace the diversity within the field, while at the same time clarifying what entrepreneurship research is and what it is not. 